\title{
Aliskiren binds to renin and prorenin bound to (pro)renin receptor in vitro
}

\author{
Kazal Boron Biswas ${ }^{1}$, AHM Nurun $\mathrm{Nabi}^{2}$, Yoshie Arai ${ }^{2}$, Tsutomu Nakagawa ${ }^{2}$, Akio Ebihara ${ }^{2}$, \\ Atsuhiro Ichihara ${ }^{3}$, Toshifumi Watanabe ${ }^{4}$, Tadashi Inagami ${ }^{5}$ and Fumiaki Suzuki ${ }^{1,2}$
}

\begin{abstract}
Human (pro)renin receptor ((P)RR) has been implicated in the augmentation of many biological and cellular processes through bindings to its ligands, renin and prorenin. In this study, we investigated the effects of aliskiren, a direct oral renin inhibitor, on the activities of free and (P)RR-bound forms of human mature renin. We also elucidated the effect of aliskiren on the 'renin activity' of the receptor-bound form of prorenin. Aliskiren had an IC $_{50}$ of $0.72 \mathrm{nmol}^{-1}$ against renin. The compound competitively inhibited renin activity with an inhibitory constant $\left(K_{\mathrm{i}}\right)$ of $0.18 \mathrm{nmol} \mathrm{I}^{-1}$. Furthermore, the dissociation constants $\left(K_{D}\right)$ for aliskiren from renin and prorenin bound to $(P) R R$ were determined using surface plasmon resonance in a BIAcore assay system (Uppsala, Sweden). These values were estimated to be $0.46 \pm 0.03$ and $0.25 \pm 0.01 \mathrm{nmol} \mathrm{I}^{-1}$, respectively. The compound competitively inhibited the renin activities of (P)RR-bound forms of both renin and prorenin with a $K_{\mathrm{i}}$ of 0.14 and $0.15 \mathrm{nmol} \mathrm{I}^{-1}$, respectively. These results indicate that aliskiren could be a potent inhibitor of the free forms of mature renin and of the receptor-bound forms of renin and prorenin.
\end{abstract}

Hypertension Research (2010) 33, 1053-1059; doi:10.1038/hr.2010.136; published online 22 July 2010

Keywords: aliskiren; direct renin inhibitor; (pro)renin receptor

\section{INTRODUCTION}

The renin-angiotensin system (RAS) has been implicated in the onset of many cardiovascular-related disorders because it regulates blood pressure and electrolyte balance. ${ }^{1-3}$ Renin is the rate-limiting enzyme in RAS, whereas prorenin is an inactive precursor of renin. ${ }^{4-6}$ The (pro)renin receptor ((P)RR), ${ }^{7}$ a new family member of the RAS, binds to both renin and prorenin and causes non-proteolytic activation of prorenin. The non-specific renin/prorenin receptors (for example, mannose-6-phosphate and the insulin-like growth factor II receptors) internalize renin/prorenin after binding, ${ }^{8}$ but do not activate prorenin to generate intracellular angiotensins. These receptors likely act as clearance proteins, which bind to, internalize and help degrade the ligands, renin and prorenin. On the other hand, $(\mathrm{P}) \mathrm{RR}$, on the cell membrane, has been reported to stimulate the 'renin activities' of renin and prorenin without internalization..$^{9-11}$ Ichihara et al. ${ }^{12,13}$ showed that $(\mathrm{P}) \mathrm{RR}$ is involved in the development of diabetic nephropathy by a mechanism that involves the receptor-associated prorenin system. In addition, Satofuka et al. ${ }^{14}$ reported that receptorassociated prorenin system has a role in retinal neovascularization. Therefore, the physiological regulation of 'renin activity' in either the free or the receptor-bound state in RAS is important for suppressing the organ-damaging progression of hypertension and managing blood pressure to prevent further tissue damage caused by the long-term adverse effects of hypertension and/or diabetes.

Inhibiting RAS through angiotensin-converting enzyme inhibitors and/or angiotensin-receptor blockers has proven to be a successful strategy for treating hypertension and related cardiovascular disorders. However, these drugs ultimately lead to an increase in plasma renin concentration and activity, thus restricting their effectiveness as RAS inhibitors. ${ }^{15,16}$ Alternatively, aliskiren, a direct human renin inhibitor, lowers blood pressure in patients with mild to moderate hypertension ${ }^{17,18}$ and shows cardiorenal protection in hypertensive double transgenic rats expressing human genes for renin and angiotensinogen. ${ }^{19}$ Aliskiren binds to the S3-S2' subsites and blocks the catalytic function of renin. ${ }^{20}$ It also binds to a large hydrophobic S1-S3 site and the newly discovered non-substrate pocket $\mathrm{S} 3{ }^{\mathrm{SP}}$ of human renin. ${ }^{20,21}$ Aliskiren induces a net reduction in plasma renin activity and in plasma angiotensin II (Ang-II) and aldosterone levels. ${ }^{22}$ Therefore, this compound could also inhibit the enhancement of renin activity by receptor-bound renin and prorenin, thus preventing the excess generation of angiotensins in tissues. In this study, we investigated the biochemical properties of aliskiren as a renin inhibitor against receptor-bound renin/ prorenin.

${ }^{1}$ Laboratory of Animal Biochemistry, United Graduate School of Agricultural Science, Gifu University, Gifu, Japan; ${ }^{2}$ Faculty of Applied Biological Sciences, Gifu University, Gifu, Japan; ${ }^{3}$ Department of Internal Medicine, Keio University School of Medicine, Tokyo, Japan; ${ }^{4}$ Novartis Pharma K.K., Tokyo, Japan and ${ }^{5}$ Department of Biochemistry, Vanderbilt University School of Medicine, Nashville, TN, USA

Correspondence: Dr F Suzuki, Laboratory of Animal Biochemistry, Faculty of Applied Biological Sciences and United Graduate School of Agricultural Science, Gifu University, 1-1 Yanagido, Gifu 501-1193, Japan.

E-mail: aob3073@gifu-u.ac.jp

Received 23 March 2010; revised 16 April 2010; accepted 23 May 2010; published online 22 July 2010 


\section{METHODS}

\section{Experimental design}

This study was carried out in vitro using highly purified renin, ${ }^{23,24}$ prore$\operatorname{nin},{ }^{9,23,24}(\mathrm{P}) \mathrm{RR}^{23,25}$ and sheep angiotensinogen. ${ }^{26}$ The standard Ang-I ELISA was used to measure renin activity as described by Suzuki et al. ${ }^{27}$

The optimal $\mathrm{pH}$ of human renin and human angiotensinogen is between 5.5 and $6.5 ; ;^{28}$ the rate of reaction decreases by about $50 \%$ at $\mathrm{pH} 7.5 .{ }^{29}$ However, the reaction between human renin and sheep angiotensinogen displays a wide plateau of maximal Ang-I generation between $\mathrm{pH} 7.2$ and 8.5. ${ }^{28}$ Furthermore, human renin has a 10 -fold higher affinity $\left(K_{\mathrm{m}}\right)$ for sheep angiotensinogen compared with the human substrate and has a fivefold faster reaction rate with sheep angiotensinogen compared with the human substrate. ${ }^{26,30} \mathrm{~A} \mathrm{pH}$ of 7.2-7.5 was chosen for our assay. Owing to the faster reaction rate with human renin, sheep angiotensinogen was used as the renin substrate in this study.

Using $0.5 \mathrm{nmoll}^{-1}$ of human recombinant renin and $0.3 \mu \mathrm{moll}^{-1}$ of sheep angiotensinogen, the reaction rate could be conveniently controlled in the present assay conditions. The maximal substrate consumption was $\sim 2-3 \%$ within $30 \mathrm{~min}$. For this reason, $0.5 \mathrm{nmoll}^{-1}$ of enzyme was used to determine the values of $\mathrm{IC}_{50}, K_{\mathrm{i}}$ and $K_{\mathrm{m}}$ in this study.

\section{Preparation of renin and prorenin}

A conditioned medium of Chinese hamster ovary cells harboring cDNA coding for human prorenin containing 383 amino-acid residues with a decahistidine at the C-terminus ${ }^{23,24,31}$ was used as a recombinant human prorenin source. The mature human renin was prepared by trypsin proteolytic cleavage of the prorenin prosegment and purified by the method of Nakagawa et al. ${ }^{24}$ The concentrations of renin and prorenin in the medium were measured using the enzyme-linked immunosorbent assay as described by Suzuki et al. ${ }^{32}$ These preparations were stored at $-80^{\circ} \mathrm{C}$ until further use. Under physiological conditions, $<2 \%$ of the total prorenin is in the open active form. ${ }^{33}$ In this study, a prorenin preparation that showed $\sim 2 \%$ activity was used. Considering this fact, prorenin was incubated at $37^{\circ} \mathrm{C}$ for $1 \mathrm{~h}$ to avoid any cryo-activation because of preservation. Following this treatment, prorenin showed $<2 \%$ of its total potential activity when compared with the activity of trypsin-treated prorenin.

\section{Preparation of human $(\mathrm{P}) \mathrm{RR}$}

The human (P)RR lacking the transmembrane part with six histidine residues tagged at the C-terminus was synthesized in a cell-free in vitro system based on wheat germ lysate according to a previously described method. ${ }^{23}$ The receptor was purified by affinity chromatography using a His-Trap column, and its presence was confirmed by SDS-PAGE and western blot analyses using an antiHis tag antibody and an antibody elicited against an antigenic sequence designed from the nearby $\mathrm{N}$-terminal sequence of the transmembrane domain. The molecular size of (P)RR lacking the transmembrane domain and the six histidine C-terminal tag was estimated to be $32.5 \mathrm{kDa}$. The binding ability of recombinant $(\mathrm{P}) \mathrm{RR}$ to its ligands, renin and prorenin has been evaluated in real time by surface plasmon resonance in a BIAcore assay system (Uppsala, Sweden). ${ }^{23,31}$

\section{Determination of $\mathrm{IC}_{50}$ of aliskiren against human recombinant renin}

Aliskiren (kindly provided by Novartis Pharma, Basel, Switzerland) was dissolved in phosphate-buffered saline at various concentrations. The $\mathrm{IC}_{50}$ of aliskiren against human recombinant renin was determined using sheep angiotensinogen $\left(0.3 \mu \mathrm{moll}^{-1}\right)$ as the substrate. After incubating renin $\left(0.5 \mathrm{nmoll}^{-1}\right)$ with different concentrations of aliskiren $(0.025,0.05,0.1$, $0.25,0.5,0.7,0.9$ and $\left.1.0 \mathrm{nmoll}^{-1}\right)$, the activity of renin was measured using standard Ang-I ELISA, ${ }^{27}$ and the IC $_{50}$ was calculated.

\section{Determination of the inhibitory constant $\left(K_{\mathrm{i}}\right)$ of aliskiren for the inhibition of renin activity}

The inhibitory constant $\left(K_{\mathrm{i}}\right)$ of aliskiren against renin activity was determined. Aliskiren, even at a concentration of $0.2 \mathrm{nmoll}^{-1}$, was able to inhibit renin activity under the present assay conditions. In this study, the free form of mature renin $\left(0.5 \mathrm{nmoll}^{-1}\right)$ was used to estimate the $K_{\mathrm{m}}$ using various concentrations $\left(0.16,0.3,0.4,0.6,1.0,1.25,1.5\right.$ and $\left.2.5 \mu \mathrm{moll}^{-1}\right)$ of angiotensinogen; the $K_{\mathrm{i}}$ of aliskiren for the inhibition of renin activity was determined with $0.2 \mathrm{nmoll}^{-1}$ aliskiren.

\section{Real-time binding of aliskiren to receptor-bound mature renin and prorenin}

Real-time binding of aliskiren to the receptor-bound mature renin and prorenin was observed using surface plasmon resonance in a BIAcore assay system. As it has been postulated that directly coupled (P)RR shows inadequate binding to renin and prorenin, ${ }^{23,31}$ an anti-(P)RR antibody was used to immobilize the receptor onto the CM5 sensor chip. In this study, an anti-His tag antibody (Qiagen GmbH, Hilden, Germany) was immobilized onto the CM5 sensor chip through amine coupling according to our previous protocol. $^{23,31}$ Briefly, the carboxy methyl group on the sensor chip was activated using 1-ethyl-3-(3-dimethyl-aminopropyl) carbodiimide and $\mathrm{N}$-hydroxysuccinimide, thus coupling with the amino groups of the proteins of interest. (P)RR $\left(30 \mathrm{nmoll}^{-1}\right)$ was injected $\left(10 \mu \mathrm{min}^{-1}\right)$ and allowed to associate with the antibody through the six histidine residues at the C-terminus of (P)RR. The control cells were activated with ethyl-3-(3-dimethyl-aminopropyl) carbodiimide/ $N$-hydroxysuccinimide, treated with buffers (HBS-EP) and finally blocked by ethanolamine. Any binding response observed in these cells was considered non-specific binding. Specific binding was obtained by subtracting non-specific binding from the total binding. Renin and prorenin $\left(0.5 \mathrm{nmoll}^{-1}\right)$ were injected $\left(10 \mu \mathrm{min}^{-1}\right)$ to bind to the immobilized receptor followed by the injection of different concentrations $\left(0.1,0.5,1.0,2.0 \mathrm{nmoll}^{-1}\right)$ of aliskiren $\left(10 \mu \mathrm{lmin}{ }^{-1}\right)$ to bind to the receptor-bound renin and prorenin. The surface was regenerated by injecting a mixture of glycine $\left(10 \mathrm{mmoll}^{-1}\right)$ and $\mathrm{NaCl}\left(150 \mathrm{mmoll}^{-1}\right)$ at $\mathrm{pH} 2.0$ to avoid repeated coupling of the anti(P)RR-antibody. The flow of renin and prorenin was stopped before beginning the flow of aliskiren. Therefore, after allowing renin and prorenin to bind to the immobilized receptors, there should be some release of the ligands from the receptors before beginning the flow of aliskiren. When we tried to determine the binding of aliskiren directly to the receptor without renin/prorenin, the resonance signal in the BIAcore assay system matched that of non-specific binding. In this case, aliskiren showed association and dissociation phases only when it was injected after renin/prorenin. The association $\left(k_{\mathrm{a}}\right)$ and dissociation $\left(k_{\mathrm{d}}\right)$ rate constants for the binding of aliskiren to the receptor-bound renin and prorenin were measured, and the dissociation constants $\left(K_{\mathrm{D}}\right)$ were determined using the Langmuir 1:1 kinetic-binding model.

\section{Real-time binding of renin-aliskiren complex to $(\mathrm{P}) \mathrm{RR}$}

The binding kinetics of the renin-aliskiren complex to $(\mathrm{P}) \mathrm{RR}$ were also tested. Renin $\left(0.5 \mathrm{nmoll}^{-1}\right)$ was pre-incubated with aliskiren $\left(0.5\right.$ and $\left.1.0 \mathrm{nmoll}^{-1}\right)$, and the aliskiren-renin complex was injected into the flow cells to observe the binding response. The association $\left(k_{\mathrm{a}}\right)$ and dissociation $\left(k_{\mathrm{d}}\right)$ rate constants for the binding of the aliskiren-renin complex to $(\mathrm{P}) \mathrm{RR}$ were measured, and the dissociation constants $\left(K_{\mathrm{D}}\right)$ were determined using the Langmuir 1:1 kineticbinding model.

\section{Inhibition of the activities of receptor-bound mature renin and prorenin by aliskiren at equilibrium}

It is difficult to maintain an equal amount of adsorbed receptors on the wells of plastic surfaces. For this reason, each experiment was repeated at least five times. A 5\% variation in the adsorbed amount of receptors from well to well and from day to day was considered negligible and acceptable. Binding methods of renin and prorenin to the pre-adsorbed receptors using the same protocol have been described in our previous studies. ${ }^{11,23,25}$ Our recent data revealed that the $K_{\mathrm{D}}$ for the binding of human prorenin to pre-adsorbed (P)RR at $4{ }^{\circ} \mathrm{C}$ at equilibrium and to immobilized (P)RR at $25^{\circ} \mathrm{C}$ in the kinetic state using a BIAcore assay system was similar $\left(\sim 1.2 \mathrm{nmoll}^{-1}\right) .{ }^{23,34}$ In this study, the binding of renin and prorenin to pre-adsorbed $(\mathrm{P}) \mathrm{RR}$ was performed at $4{ }^{\circ} \mathrm{C}$ at equilibrium. ${ }^{11,23,25}$ Briefly, after diluting the original human (P)RR preparation, $100 \mu \mathrm{l}$ aliquots ( $\sim 15 \mathrm{nmoll}^{-1}$ of receptor in PBS) were allowed to immobilize on the plastic surface of a 96 -well plate at $4{ }^{\circ} \mathrm{C}$ for $24 \mathrm{~h}$ and then blocked with blocking buffer $(0.1 \%$ casein in phosphate-buffered saline). Renin 
and prorenin $\left(0.5 \mathrm{nmoll}^{-1}\right)$ were incubated in $100 \mu \mathrm{l}$ medium with preadsorbed (P)RR at $4{ }^{\circ} \mathrm{C}$ for $1 \mathrm{~h}$, and after removing the medium, the wells were washed with ice-cold PBS. The $K_{\mathrm{m}}$ and $K_{\mathrm{i}}$ values were determined from the rate of Ang-I production, whereas different concentrations of angiotensinogen were used in the absence and presence of $0.2 \mathrm{nmoll}^{-1}$ of aliskiren. The reaction mixture contained angiotensinogen, serine protease inhibitor (4-(2-aminoethyl) benzenesulfonyl fluoride hydrochloride or AEBSF at $0.1 \mathrm{mg} \mathrm{m}^{-1}$ ) and aliskiren in the solution of $\mathrm{NaCl}$ and $\mathrm{NaH}_{2} \mathrm{PO}_{4}$ in $0.1 \%$ bovine serum albumin at $\mathrm{pH}$ 7.35. The generation of Ang-I was carried out at $37^{\circ} \mathrm{C}$ for $30 \mathrm{~min}$ to determine the enzymatic activities of receptor-bound mature renin and prorenin as described previously. ${ }^{9,11,23,27}$ In the present assay, considering the values of $K_{\mathrm{D}}$ for $(\mathrm{P}) \mathrm{RR}$ with renin $\left(4 \mathrm{nmoll}^{-1}\right)^{23,31}$ and prorenin $\left(1.0 \mathrm{nmoll}^{-1}\right)^{23,31}$ at the equilibrium state, almost all ligands (renin/ prorenin) were probably bound to (P)RR during Ang-I generation. The renin activities of the receptor-bound renin and prorenin were determined from the linear regression curves (Figures $5 \mathrm{~b}$ and $6 \mathrm{~b}$, respectively) obtained after generating Michaelis-Menten curves of renin activity (ng Ang-I per ml per hour) vs. the concentration of angiotensinogen (Figures 5a and 6a, respectively).

\section{RESULTS}

\section{$\mathrm{IC}_{50}$ of aliskiren against the enzymatic activity of human}

\section{recombinant renin}

The half maximal inhibitory concentration (that is the $\mathrm{IC}_{50}$ of aliskiren) for the inhibition of renin activity was estimated to be $0.72 \mathrm{nmoll}^{-1}$. Figure 1 indicates the $\mathrm{IC}_{50}$ of aliskiren required to inhibit renin activity.

\section{$K_{\mathrm{i}}$ of aliskiren for the inhibition of human renin activity}

Inhibition of renin activity was clearly observed by plotting renin activity $v$ s. different concentrations of angiotensinogen (as shown in Figure 2a) in the presence or absence of aliskiren. Linear regression analysis of the double-reciprocal plot (Figure 2b) of the MichaelisMenten curve indicated competitive inhibition of renin by aliskiren. The $K_{\mathrm{m}}$ of human mature renin (soluble form) for sheep angiotensinogen was $0.16 \mu \mathrm{moll}^{-1}$, whereas the inhibition constant $\left(K_{\mathrm{i}}\right)$ of aliskiren for the inhibition of renin activity was $0.18 \mathrm{nmoll}^{-1}$, as shown in Figure 2b.

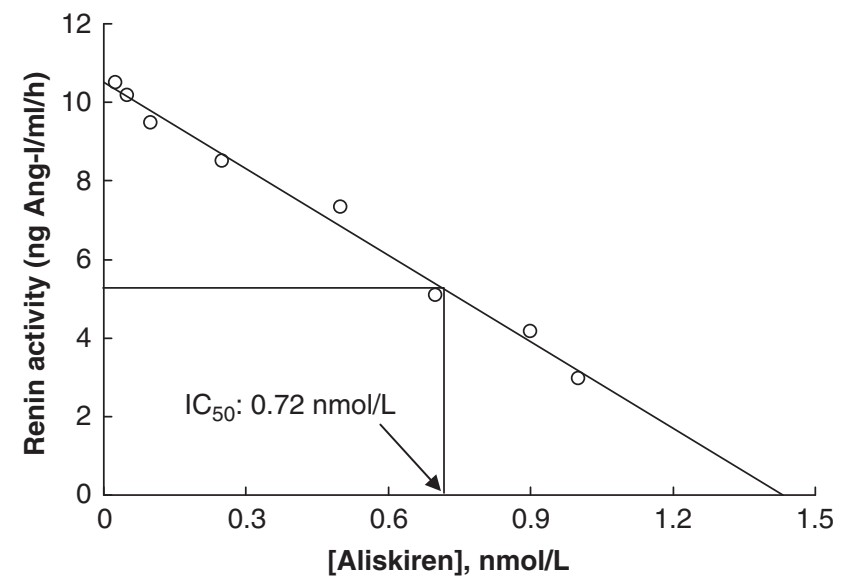

Figure 1 Determination of $I_{50}$ of aliskiren against human mature renin using sheep angiotensinogen as the substrate. Different concentrations of aliskiren were incubated with recombinant human mature renin $\left(0.5 \mathrm{nmoll}^{-1}\right)$ and sheep angiotensinogen at $37^{\circ} \mathrm{C}$ and $\mathrm{pH}$ 7.0. The $1 \mathrm{C}_{50}$ was estimated by determining the concentration of aliskiren needed to inhibit renin by half of its maximum activity; each data point represents of the average value of five identical experiments.
Binding of aliskiren to receptor-bound mature renin and prorenin Binding of aliskiren to the renin-receptor and prorenin-receptor complexes was observed in the BIAcore assay system using surface plasmon resonance, as shown in Figures $3 a$ and $4 a$, respectively. All data were fit globally to a 1:1 Langmuir-binding model for both the association and dissociation phases at several concentrations simultaneously using the BIAevaluation software. In addition, Figures $3 \mathrm{~b}$ and $4 \mathrm{~b}$ show dose-dependent binding of aliskiren to recombinant human mature renin and prorenin associated with $(\mathrm{P}) \mathrm{RR}$, respectively, obtained by BIAsimulation software. The association $\left(k_{\mathrm{a}}\right)$ and dissociation $\left(k_{\mathrm{d}}\right)$ rate constants for the binding of aliskiren to reninreceptor and prorenin-receptor complexes were $(1.92 \pm 0.18) \times 10^{8}$ and $(1.7 \pm 0.22) \times 10^{8}\left(1 \mathrm{~mol}^{-1}\right) \mathrm{s}^{-1}$ as well as $(8.9 \pm 1.52) \times 10^{-2}$ and $(4.29 \pm 1.17) \times 10^{-2} \mathrm{~s}^{-1}$, respectively. The dissociation constants $\left(K_{\mathrm{D}}\right)$ for the binding of aliskiren to receptor-bound mature renin and prorenin were $0.46 \pm 0.03$ and $0.25 \pm 0.01 \mathrm{nmoll}^{-1}$, respectively.

\section{Binding of renin-aliskiren complex to the $(\mathrm{P}) \mathrm{RR}$}

Binding of the renin-aliskiren complex to $(\mathrm{P}) \mathrm{RR}$ was observed by surface plasmon resonance using BIAcore (Figures $3 \mathrm{c}$ and $\mathrm{d}$ ). The binding

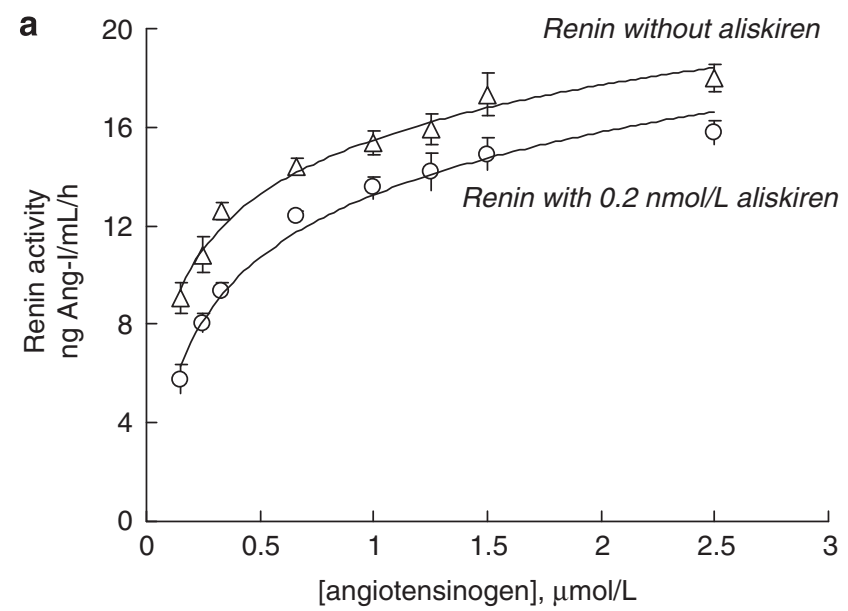

b

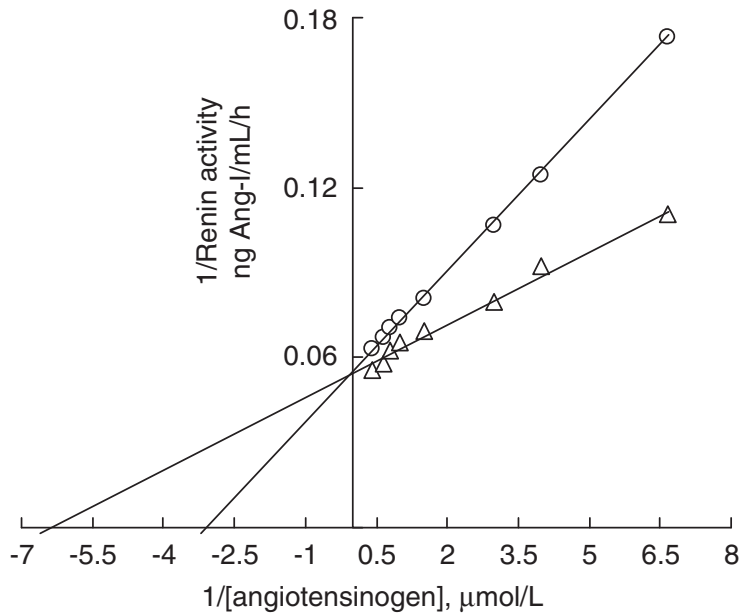

Figure 2 (a) Shows saturation curves for the activity of human mature renin $\left(0.5 \mathrm{nmol} \mathrm{I}^{-1}\right)$ at different concentrations of sheep angiotensinogen with (open circles) or without (open triangles) $0.2 \mathrm{nmoll}^{-1}$ of aliskiren. (b) Represents the Lineweaver-Burk plots (depicted from the average values of each experiment, $n=5$ ) for determination of the $K_{\mathrm{m}}$ (open triangles) of free renin and $K_{\mathrm{i}}$ (open circles) of aliskiren for the inhibition of renin activity. The $K_{\mathrm{i}}\left(0.18 \mathrm{nmol} \mathrm{I}^{-1}\right)$ was determined using the following equation: $K_{\text {mapp }}=K_{\mathrm{m}} \times\left(1+[i] / K_{\mathrm{i}}\right)$, where $K_{\mathrm{m}}$ and $K_{\text {mapp }}$ for renin were 0.16 and $0.33 \mu \mathrm{mol}^{-1}$, respectively. 
Binding of aliskiren to the renin-(P)RR complex
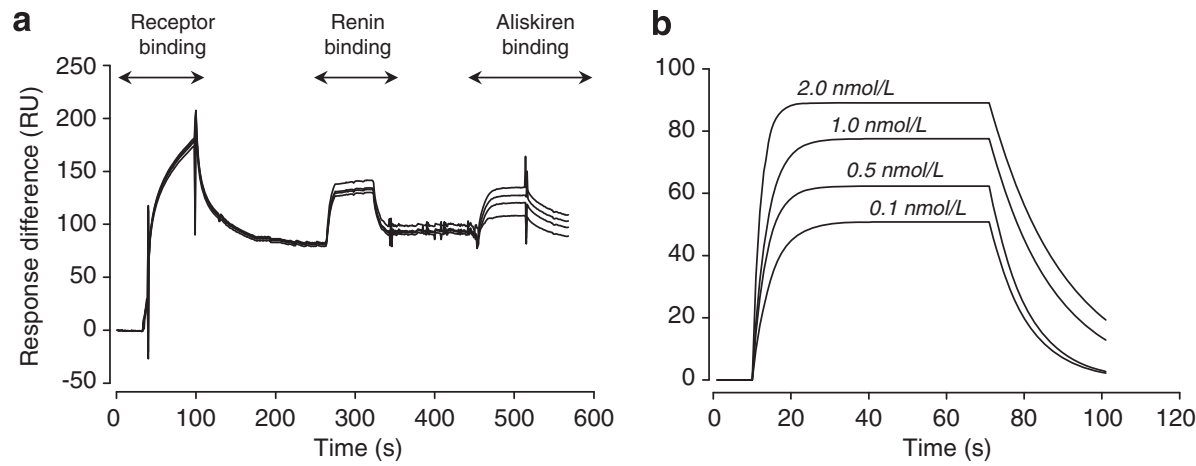

Binding of renin-aliskiren complex to $(P) R R$
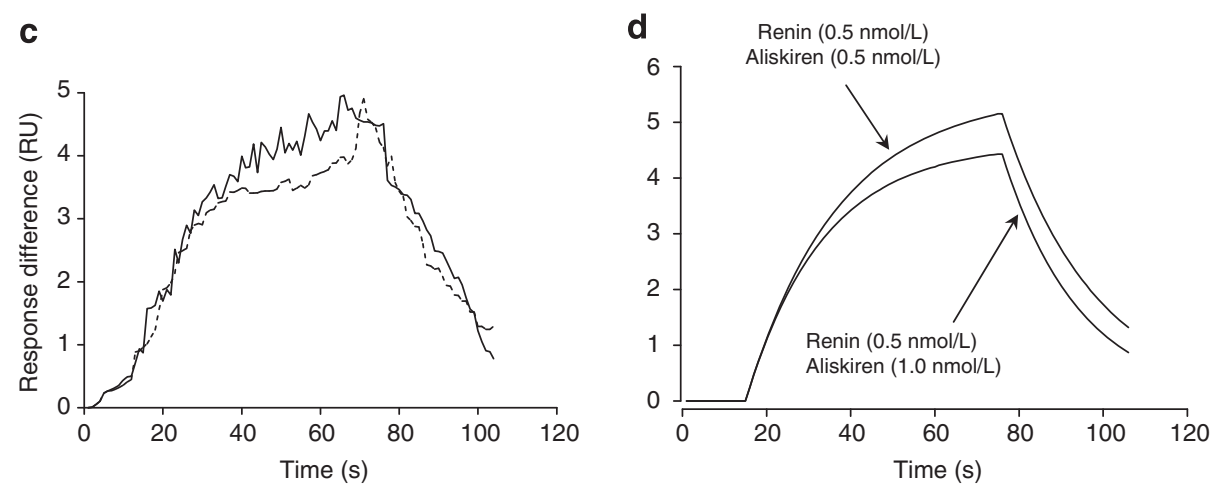

Figure 3 Binding of aliskiren to receptor-associated renin and renin-aliskiren complex to (P)RR. (a) Sensogram represents typical stepwise binding of the receptor to the anti-(pro)renin receptor ((P)RR)-antibody, of renin to (P)RR and of aliskiren to the renin-receptor complex. Previous studies have shown that direct immobilization of (P)RR onto the CM5 sensor chip caused poor binding of the ligands, whereas immobilization of (P)RR through an anti-(P)RRantibody revealed good interaction between receptor and ligand, as reflected by the resonance signal. The sensograms were corrected by subtracting the specific binding from the non-specific binding. (b) Binding of aliskiren to receptor-bound renin constructed by BIAsimulation software using association ( $k_{a}$ ) and dissociation $\left(k_{\mathrm{d}}\right)$ rates from typical binding sensograms after background subtraction. Each data point represents the average value of four identical experiments. (c) Renin was pre-incubated with $0.5 \mathrm{nmoll}^{-1}$ (dotted lines) and $1.0 \mathrm{nmol} \mathrm{I}^{-1}$ (solid line) of aliskiren, and the renin-aliskiren complex was allowed to bind to (P)RR. (d) BIAsimulation was constructed from the $k_{\mathrm{a}}$ and $k_{\mathrm{d}}$ values obtained from (c).
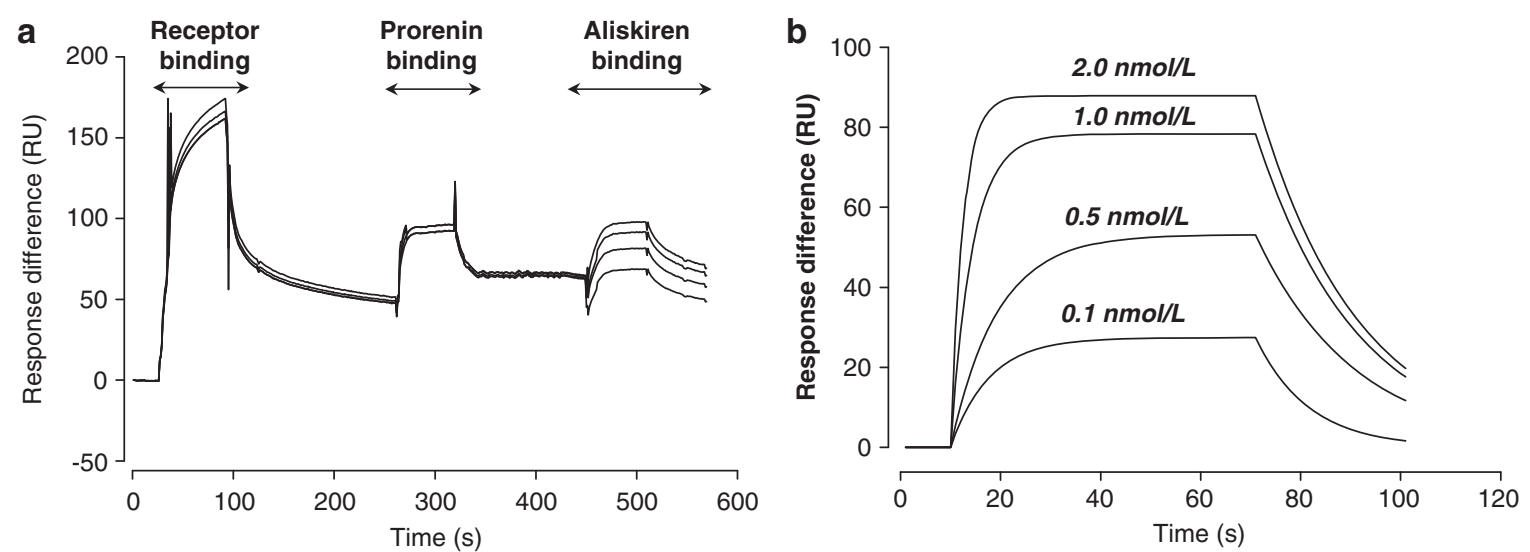

Figure 4 Binding of aliskiren to receptor-associated prorenin. (a) Sensogram represents typical stepwise binding of the receptor to the anti-(pro)renin receptor $((P) R R)$-antibody, of prorenin to (P)RR and of aliskiren to the prorenin-receptor complex. The sensograms were corrected by subtracting the specific binding from the non-specific binding. (b) Binding of aliskiren to receptor-associated prorenin obtained by BIAsimulation software using association ( $k_{\mathrm{a}}$ ) and dissociation $\left(k_{d}\right)$ rates from typical binding sensograms after background subtraction. Each data point represents the average value of four identical experiments.

kinetics of the complex to (P)RR differed from the binding kinetics of free renin. The $K_{\mathrm{D}}$ for the binding of the renin-aliskiren complex to (P)RR was $4.54 \times 10^{-5} \mathrm{moll}^{-1}$ (using $0.5 \mathrm{nmoll}^{-1}$ of aliskiren) and
$5.43 \times 10^{-5} \mathrm{moll}^{-1}$ (using $1.0 \mathrm{nmoll}^{-1}$ of aliskiren) calculated from their respective association $\left(k_{\mathrm{a}}=1.0 \times 10^{3}\left(1 \mathrm{~mol}^{-1}\right) \mathrm{s}^{-1}\right.$ for both cases) and dissociation $\left(k_{\mathrm{d}}=0.0454 \mathrm{~s}^{-1}\right.$ and $0.0543 \mathrm{~s}^{-1}$, respectively) rate constants. 
Inhibition constant $\left(K_{\mathrm{i}}\right)$ of aliskiren for the inhibition of receptorbound renin and prorenin at equilibrium

At equilibrium, the average percentages of renin and prorenin bound to the pre-adsorbed receptors were estimated to be approximately 25 and $27 \%$, respectively, and the average percentages of renin and prorenin bound to the wells without receptors were 5 and $7 \%$, respectively, as we have previously reported. ${ }^{23}$ The activities of receptor-bound renin/prorenin shown in Figures 5 and 6 were calculated after adjusting the values with those of the controls. The $K_{\mathrm{m}}$ estimated for the receptor-bound renin and prorenin was similar $\left(0.16 \mu \mathrm{moll}^{-1}\right)$, whereas the $K_{\mathrm{i}}$ values of aliskiren were 0.145 and $0.153 \mathrm{nmoll}^{-1}$, respectively, as shown in Figures $5 \mathrm{~b}$ and $6 \mathrm{~b}$.

\section{DISCUSSION}

In this study, the binding affinity and inhibitory effects of aliskiren were elucidated for renin and prorenin bound to (P)RR (Figures 3-6). This study showed that aliskiren binds to receptor-renin and receptor-prorenin complexes (Figures $3 \mathrm{a}, \mathrm{b}$ and $4 \mathrm{a}, \mathrm{b}$ ) and inhibits the renin activities of receptor-bound renin and prorenin in vitro (Figures $5 \mathrm{a}, \mathrm{b}$ and $6 \mathrm{a}, \mathrm{b})$. Our findings revealed that aliskiren bound to (P)RRassociated renin and activated prorenin with a $K_{\mathrm{D}}$ of $0.46 \pm 0.03$ and $0.25 \pm 0.01 \mathrm{nmoll}^{-1}$, respectively. Previous studies have shown that aliskiren does not inhibit the binding of either ${ }^{125} \mathrm{I}$-renin or ${ }^{125} \mathrm{I}$ prorenin to $(\mathrm{P}) \mathrm{RR} ;{ }^{35}$ however, it significantly decreases the expression
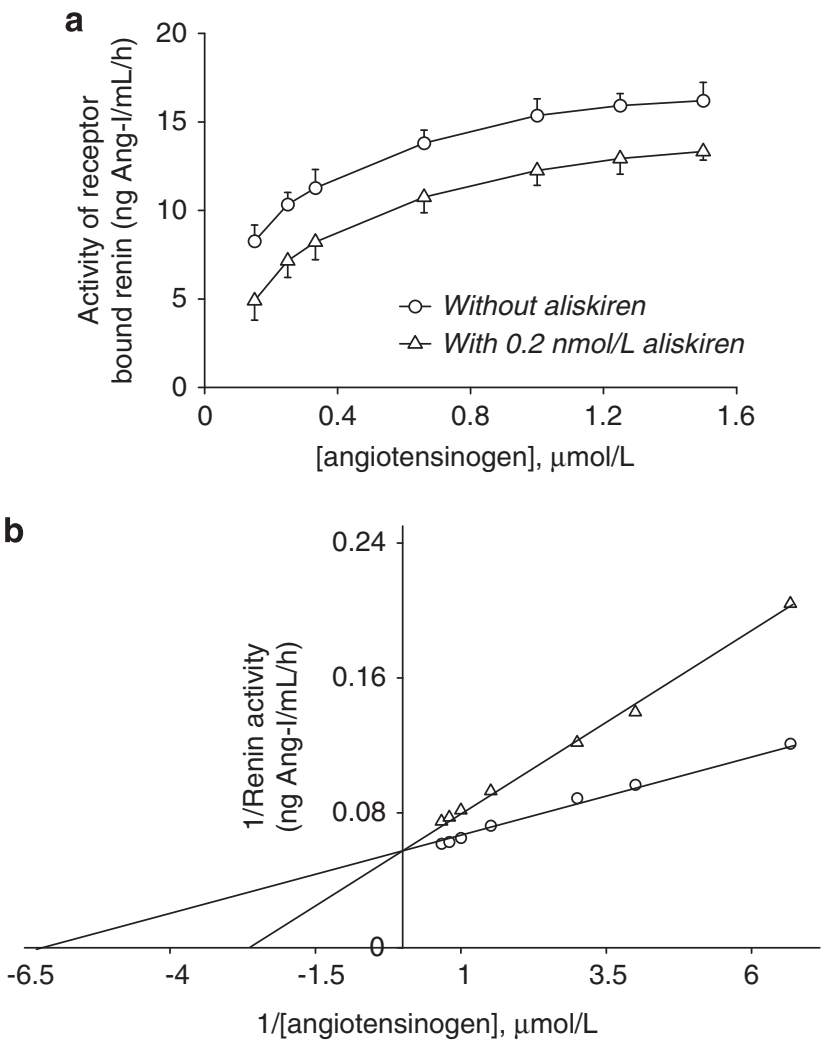

Figure 5 Determination of the inhibitory constant $\left(K_{\mathrm{i}}\right)$ of aliskiren for the inhibition of renin activity of renin bound to (pro)renin receptor ((P)RR). (a) A Michaelis-Menten curve was constructed by plotting 'renin activity' (ng Ang-l per $\mathrm{ml}$ per hour) of receptor-bound renin vs. concentration of substrate. (b) Lineweaver-Burk linear regression (using the average values of each experiment, $n=5$ ) of the Michaelis-Menten plot suggests competitive inhibition of renin activity for receptor-bound renin by aliskiren. The average value of $K_{\mathrm{i}}\left(0.145 \mathrm{nmoll}^{-1}\right)$ was calculated using $K_{\mathrm{mapp}}=K_{\mathrm{m}} \times\left(1+[\mathrm{i}] / K_{\mathrm{i}}\right)$, where $K_{\text {mapp }}=0.384 \mu \mathrm{mol} \mathrm{I}^{-1} ; K_{\mathrm{m}}=0.162 \mu \mathrm{mol} \mathrm{I}^{-1} ;[\mathrm{i}]=0.2 \mathrm{nmol} \mathrm{I}^{-1}$. of (P)RR in the kidney cortex of diabetic hypertensive Ren2 rats. ${ }^{36}$ In this study, as shown in Figures $3 \mathrm{c}$ and $\mathrm{d}$, we found that the binding kinetic parameters of renin depended on whether it had been preincubated with aliskiren. The binding affinity (dissociation constant, $K_{\mathrm{D}}$ ) of the complex for (P)RR decreased $>1000$-fold compared with that of free renin $\left(7.1 \times 10^{-9} \mathrm{M}\right) .{ }^{31}$ Interestingly, with increasing concentrations of aliskiren, binding to (P)RR became more difficult for the renin-aliskiren complex (shown in Figures $3 \mathrm{c}$ and d). Recently, Nabi et al. ${ }^{23}$ suggested that the 'hinge' region, present both in prorenin and mature renin, has a crucial role in the binding of renin/prorenin to $(\mathrm{P}) \mathrm{RR}$. This region is located near the bottom part of the active site of renin, as predicted from the stereo-structure of renin. ${ }^{23}$ The apparent values for the binding kinetics of the renin-aliskiren complex to $(\mathrm{P}) \mathrm{RR}$ suggest that binding of aliskiren to the active site of renin may modify the local conformation along with the 'hinge' region of renin, which might be reflected in the lower affinity of the renin-aliskiren complex to (P)RR. Thus, treatment with aliskiren could inhibit tissue damage mediated by the free form of renin and by (P)RR-renin/prorenin complex-generated Ang-I-dependent and -independent pathways.

Prorenin has previously been reported to have a higher binding affinity for (P)RR compared with mature renin. ${ }^{1,23,31}$ The physiological concentration of prorenin is 10 times higher than renin in human plasma. Moreover, the agonistic role of prorenin to the receptor might contribute to the pathophysiology of microvascular complications in diabetes based on the fact that high levels of plasma prorenin have been reported in diabetic subjects. ${ }^{37,38}$ Prorenin
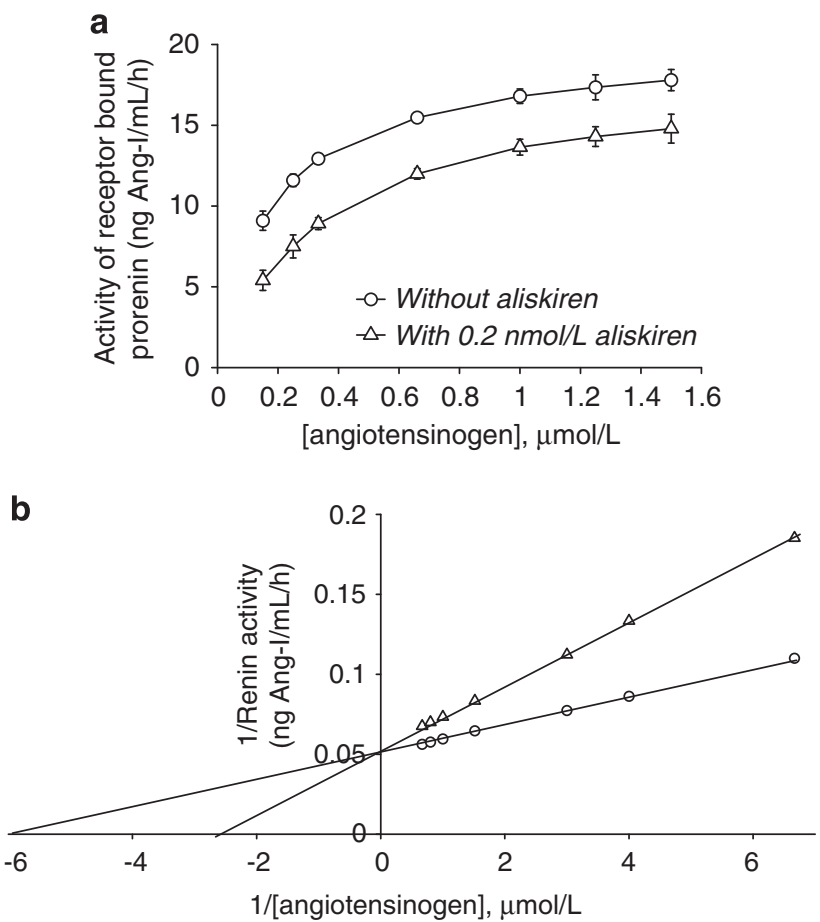

Figure 6 Determination of the inhibitory constant $\left(K_{\mathrm{i}}\right)$ of aliskiren for the inhibition of renin activity of prorenin bound to (pro)renin receptor ((P)RR). (a) A Michaelis-Menten curve was constructed by plotting 'renin activity' (ng Ang-I per $\mathrm{ml}$ per hour) of receptor-bound prorenin vs. concentration of substrate. (b) Lineweaver-Burk linear regression (using the average values of each experiment, $n=5$ ) of the Michaelis-Menten plot suggests competitive inhibition of renin activity for receptor-bound prorenin by aliskiren. The average value of $K_{\mathrm{i}}\left(0.153 \mathrm{nmolI}^{-1}\right)$ was calculated using $K_{\text {mapp }}=K_{\mathrm{m}} \times$ $\left(1+[\mathrm{i}] / K_{\mathrm{i}}\right)$, where $K_{\text {mapp }}=0.384 \mu \mathrm{mol} \mathrm{I}^{-1} ; K_{\mathrm{m}}=0.167 \mu \mathrm{mol} \mathrm{I}^{-1} ;[\mathrm{i}]=0.2 \mathrm{nmol} \mathrm{I}^{-1}$. 

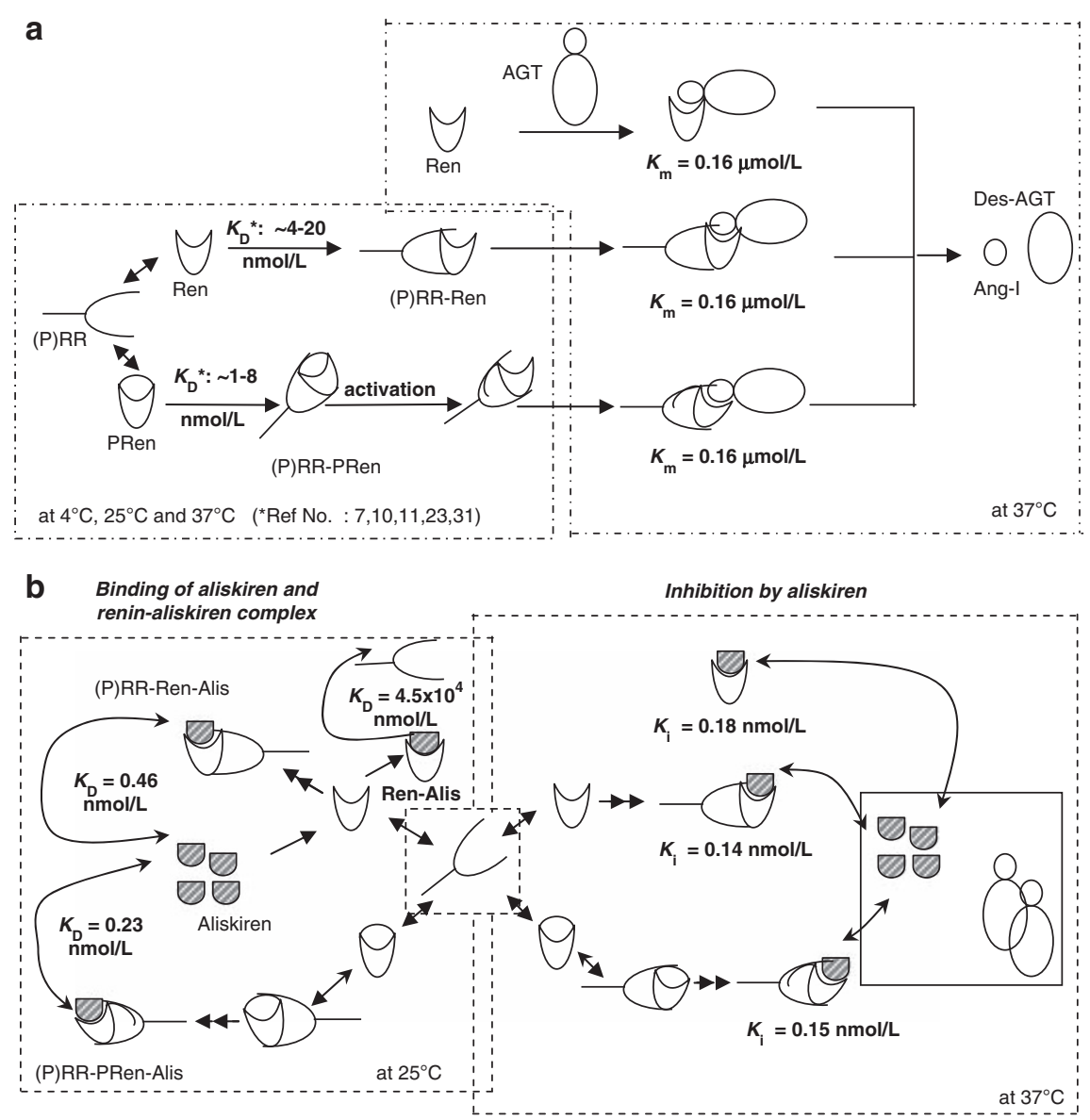

Figure 7 Schematic representation of kinetic properties of the binding of aliskiren to (P)RR-bound renin and prorenin and inhibition of their renin activities. (a) Binding of renin and prorenin to (pro)renin receptors under different conditions and determination of $K_{\mathrm{m}}{ }^{7,9-11,23,31}$ (b) Binding kinetics of aliskiren to the receptor-associated renin/prorenin and the renin-aliskiren complex to (P)RR at $25^{\circ} \mathrm{C}$ and the inhibitory constant of aliskiren for the 'renin activities' at $37^{\circ} \mathrm{C}$. AGT, angiotensinogen; Alis, aliskiren; Ang-I, angiotensin-I; des AGT, des (angiotensin-I) angiotensinogen; PRen, prorenin; (P)RR, (pro)renin receptor; Ren, renin; Ren-Alis, renin-aliskiren complex.

molecules become functionally active through a local conformational change induced upon binding to (P)RR, which accounts for the activation of the tissue-specific RAS. ${ }^{7,9-11}$ In this study, aliskiren bound to prorenin associated to (P)RR with a similar $K_{\mathrm{D}}$ to that of renin bound to $(\mathrm{P}) \mathrm{RR}$ (Figures $3 \mathrm{~b}$ and $4 \mathrm{~b}$ ). Hence, the renin inhibitor would ultimately block the activation of Ang-II generation by receptor-bound-activated prorenin in tissues.

The $\mathrm{IC}_{50}$ (half of the inhibitory concentration) for inhibition by aliskiren of renin in plasma was measured to be $0.6 \mathrm{nmoll}^{-1}$ in vitro by Wood et al. ${ }^{20}$ In this study, we used recombinant sheep angiotensinogen as a substrate to observe the in vitro activity of recombinant human renin. The $\mathrm{IC}_{50}$ of aliskiren against human mature renin was confirmed to be similar $\left(0.72 \mathrm{nmoll}^{-1}\right)$ to that reported by Wood et al. ${ }^{20}$ Moreover, in this study, the $K_{\mathrm{m}}$ of the free and receptor-bound forms of human mature renin as well as receptor-bound prorenin (non-proteolytically activated) was similar $\left(0.16 \mu \mathrm{moll}^{-1}\right)$ using the sheep substrate. In contrast, Nguyen et al. ${ }^{7}$ reported the $K_{\mathrm{m}}$ $\left(0.15 \mu \mathrm{moll}^{-1}\right)$ of human angiotensinogen to renin bound to $(\mathrm{P}) \mathrm{RR}$ was lower than that of the free form $\left(1.11 \mu \mathrm{moll}^{-1}\right)$. Earlier, using same substrate, we reported similar $K_{\mathrm{m}}$ values $\left(3.33 \mu \mathrm{moll}^{-1}\right)$ for rat mature renin and prorenin in the free or receptor-bound forms. ${ }^{11}$ These differences could be due to the use of different substrates (human or sheep angiotensinogen) that have different binding affinities for the enzymes (human or rat renin). Considering the $K_{\mathrm{i}}$ for free renin $\left(0.18 \mathrm{nmoll}^{-1}\right)$ and the $K_{\mathrm{i}}$ of aliskiren for renin and activated prorenin bound to pre-adsorbed receptors $(0.145$ and $0.153 \mathrm{nmoll}^{-1}$, respectively) at equilibrium, it is obvious that aliskiren could potently inhibit renin activities mediated by any form of renin. Figures $7 \mathrm{a}$ and $\mathrm{b}$ illustrate the properties of free and (P)RR-bound renin as well as $(\mathrm{P}) \mathrm{RR}$-bound prorenin reactions with angiotensinogen in the presence and absence of aliskiren at physiological $\mathrm{pH}$.

(P)RR mRNA is expressed in many organs such as the liver, kidney, heart and brain. ${ }^{7}$ In contrast, renal renin and/or prorenin need to be taken up from the bloodstream in the heart and vascular wall to generate Ang-I because these organs do not express renin, and the diffusion of renin cannot explain its levels in cardiac tissues. ${ }^{33}$ Thus, (P)RR could act as a means of capturing renin and/or prorenin to transport these molecules from the bloodstream into specific tissues and activate the local RAS. ${ }^{10,33}$ In vitro and animal studies have shown that increased receptor expression may be linked to high blood pressure and to cardiac and glomerular fibrosis by activating mitogen-activated protein kinases and by upregulating gene expression of profibrotic molecules. ${ }^{39}$ Other studies also suggest that the receptor is involved in diabetic nephropathy by activating receptor-bound prorenin. ${ }^{12}$ Considering the pathophysiological involvement and importance of $(\mathrm{P}) \mathrm{RR}$ associated with either renin or prorenin, we found that aliskiren inhibited the activities of receptor-bound renin and prorenin with $K_{\mathrm{i}}$ values of 0.145 and $0.153 \mathrm{nmoll}^{-1}$, respectively 
(Figures $5 \mathrm{~b}$ and $6 \mathrm{~b}$ ). Similar findings have been reported by Krop et al., ${ }^{36}$ who studied aliskiren binding to prorenin in vivo. In Figures $2 \mathrm{~b}, 5 \mathrm{~b}$ and $6 \mathrm{~b}$, aliskiren appears to competitively inhibit the activities of both free renin and receptor-bound renin/prorenin. There seem to be eight subsites in the active site of recombinant human renin. ${ }^{40}$ Among them, S5 and S3 subsites are important for enzymatic activity, whereas our previous study has shown that subsites P2 (His 9) and P3 (His 19) in angiotensinogen are important for its interaction with the catalytic sites of renin. ${ }^{41}$ Wood et al. ${ }^{20}$ proposed that aliskiren occupies the $\mathrm{S} 3$ and $\mathrm{S} 2$ subsites, thereby blocking the catalytic function of renin. As both of these subsites are crucial in the binding of angiotensinogen to renin, blocking these sites would ultimately block binding of angiotensinogen. Thus, from our experimental data, we suggest that aliskiren competitively inhibits the catalytic activity of renin.

In conclusion, our study reveals that aliskiren binds not only to the free and receptor-bound forms of renin, but also to receptor-bound prorenin and thus inhibits their renin activities in vitro. Therefore, this compound is a potent inhibitor that can reduce the detrimental effects that are caused by Ang-I generated by the activity of receptor-bound renin and activated prorenin.

\section{ACKNOWLEDGEMENTS}

This study was supported in part by a Grant-in-aid for Scientific Research (1907165) from the Ministry of Education, Science and Culture of Japan and an NIH grant (HL58205).

1 Re RN. Cellular biology of the renin-angiotensin systems. Arch Intern Med 1984; 144: 2037-2041.

2 Lever AF. Renin: endocrine, paracrine, or part-paracrine control of blood pressure? Am J Hypertens 1989; 2: 276-285.

3 Campbell DJ. Extrarenal renin and blood pressure regulation: an alternative viewpoint. Am J Hypertens 1989; 2: 266-275.

4 Baxter JD, Perloff D, Hsueh W, Biglieri EG. The endocrinology of hypertension. In: Felig P, Baxter JD and Frohman LA (eds). Endocrinology and Metabolism. 3rd edn. McGrawHill: New York, 1995, pp 749-853.

5 Lutterotti NV, Catanzaro DF, Sealey JE, Laragh JH. Renin is not synthesized by cardiac and extrarenal vascular tissues: a review of experimental evidence. Circulation 1994; 89: 458-470.

6 Prieto-Carrasquero MC, Harrison-Bernard LM, Kobori H, Ozawa Y, Hering-Smith KS, Hamm LL, Navar LG. Enhancement of collecting duct renin in angiotensin II-dependent hypertensive rats. Hypertension 2004; 44: 223-229.

7 Nguyen G, Delarue F, Burckle C, Bouzhir L, Giller T, Sraer JD. Pivotal role of the renin prorenin receptor in angiotensin II production and cellular responses to renin. J Clin Invest 2002; 109: 1417-1427.

8 van Kesteren CAM, Danser AHJ, Derkx FHM, Dekkers DHW, Lamers JMJ, Saxena PR, Schalekamp MADH. Mannose 6-phosphate receptor-mediated internalization and activation of prorenin by cardiac cells. Hypertension 1997; 30: 1389-1396.

9 Nurun NA, Uddin MN, Nakagawa T, Iwata H, Ichihara A, Inagami T, Suzuki F. Role of 'handle' region of prorenin prosegment in the non-proteolytic activation of prorenin by binding to membrane anchored (pro)renin receptor. Front Biosci 2007; 12: $4810-4817$

10 Batenburg WW, Krop M, Garrelds IM, de Vries R, de Bruin RJ, BurckI CA, Müller DN, Bader M, Nguyen G, Danser AH. Prorenin is the endogenous agonist of the (pro)renin receptor. Binding kinetics of renin and prorenin in rat vascular smooth muscle cells overexpressing the human (pro)renin receptor. J Hypertens 2007; 25: 2441-2453.

11 Nabi AHMN, Kageshima A, Uddin MN, Nakagawa T, Park EY, Suzuki F. Binding properties of rat prorenin and renin to the recombinant rat renin/prorenin receptor prepared by a baculovirus expression system. Int J Mol Med 2006; 8: 483-488.

12 Ichihara A, Sakoda M, Mito-Karauchi A, Itoh H. Activated prorenin as therapeutic target for diabetic nephropathy. Diab Res Clin Prac 2008; 825: S63-S66.

13 Ichihara A, Hayashi M, Kaneshiro Y, Suzuki F, Nakagawa T, Tada Y, Koura Y, Nishiyama A, Okada H, Uddin MN, Nabi AHMN, Ishida Y, Inagami T, Saruta T. Inhibition of diabetic nephropathy by a decoy peptide corresponding to the 'handle' region for nonproteolytic activation of prorenin. J Clin Invest 2004; 114: 1128-1135.

14 Satofuka S, Ichihara A, Nagai N, Koto T, Shinoda H, Noda K, Ozawa Y, Inoue M, Tsubota K, Itoh H, Oike Y, Ishida S. Role of nonproteolytically activated prorenin in pathologic, but not physiologic, retinal neovascularization. Invest Ophthalmol Vis Sci 2007: 48: 422-429.
15 Azizi M, Menard J. Combined blockade of the renin-angiotensin system with angiotensin-converting enzyme inhibitors and angiotensin II type 1 receptor antagonists. Circulation 2004; 109: 2492-2499.

16 Mooser V, Nussberger J, Jullierat L. Reactive hyperreninemia is a major determinant of plasma angiotensin II during ACE inhibition. J Cardiovasc Pharmacol 1990; 15: 276-282.

17 Gradman A, Schmieder RE, Lins RL, Nussberger J, Chiang Y, Bedigian MP. Aliskiren a novel orally effective renin inhibitor, provides dose-dependent antihypertensive efficacy and placebo-like tolerability in hypertensive patients. Circulation 2005; 111: 1012-1018.

18 Stanton A, Jensen C, Nussberger J, O'Brien E. Blood pressure lowering in essential hypertension with an oral renin inhibitor, aliskiren. Hypertension 2003; 42: 1137-1143.

19 Pilz B, Shagdarsuren E, Wellner M, Fiebeler A, Dechend R, Gratze P, Meiners S, Feldman DL, Webb RL, Garrelds IM, Danser AHJ, Luft F, Müller DN. Aliskiren a human renin inhibitor, ameliorates cardiac and renal damage in double-transgenic rats. Hypertension 2005; 46: 569-576.

20 Wood JM, Maibaum J, Rahuel J, Grütter MG, Cohen NC, Rasetti V, Rüger H, Göschke R, Stutz S, Fuhrer W, Schilling W, Rigollier P, Yamaguchi Y, Cumin F, Baum HP, Schnell CR, Herold P, Mah R, Jensen C, O'Brien E, Stanton A, Bedigian MP. Structure-based design of aliskiren a novel orally effective renin inhibitor. Biochem Biophys Res Commun 2003; 308: 698-705.

21 Rahuel J, Rasetti V, Maibaum J, Rüeger H, Göschke R, Cohen NC, Stutz S, Cumin F, Fuhrer W, Wood JM, Grütter MG. Structure-based drug design: the discovery of novel nonpeptide orally active inhibitors of human renin. Chem Biol 2000; 7: 493-504.

22 Jeunemaitre X, Menard J, Nussberger J, Guyene TT, Brunner HR, Corvol P. Plasma angiotensins, renin, and blood pressure during acute renin inhibition by CGP $38560 \mathrm{~A}$ in hypertensive patients. Am J Hypertens 1989; 2: 819-827.

23 Nabi AHMN, Biswas KB, Nakagawa T, Ichihara A, Inagami T, Suzuki F. Prorenin has high affinity multiple binding sites for (pro)renin receptor. Biochim Biophys Acta 2009; 1794: 1838-1847.

24 Nakagawa T, Nishiuchi K, Akaki J, Iwata H, Satou R, Suzuki F, Nakamura Y. Efficient production of recombinant human (pro)renin utilizing a decahistidine tag attached at the C-terminus. Biosci Biotechnol Biochem 2007; 71: 256-260.

25 Biswas KB, Nabi AHMN, Arai Y, Nakagawa T, Ebihara A, Suzuki F. Species specificity of prorenin binding to the (pro)renin receptor in vitro. Front Biosci 2010; E2: 1234-1240.

26 Nagase M, Suzuki F, Sawai Y, Orihashi T, Inui Y, Nakagawa T, Nakamura Y. Purification and some properties of recombinant sheep angiotensinogen expressed in Chinese hamster ovary cells. Biomed Res 1997; 18: 439-443.

27 Suzuki F, Yamashita S, Takahashi A, Ito M, Miyazaki S, Nagata Y, Nakamura Y. Highly sensitive microplate-ELISA for angiotensin I using 3,3',5,5'- tetramethylbenzidine. Clin Exp Hypertens A 1990; 12: 83-95.

28 Hummerich W, Krause DK. Improvement of renin determination in human plasma using a commonly available renin standard a radioimmunological method. Klin Wochenschr 1975; 53: 559-569.

29 Sealey JE, Laragh JH. Searching out low renin patients: limitations of some commonly used methods. Am J Med 1973; 55: 303-314.

30 Skinner SL. Improved assay methods for renin 'concentration' and 'activity' in human plasma. Methods using selective denaturation of renin substrate. Circ Res 1967; 20 . 391-402.

31 Nabi AHMN, Biswas KB, Nakagawa T, Ichihara A, lanagami T, Suzuki F. 'Decoy peptide' region (RIFLKRMPSI) of prorenin prosegment plays a crucial role in prorenin binding to the (pro)renin receptor. Int J Mol Med 2009; 24: 83-89.

32 Suzuki F, Hayakawa M, Nakagawa T, Nasir UM, Ebihara A, Iwasawa A, Ishida Y, Nakamura Y, Murakami K. Human prorenin has 'gate and handle' regions for its nonproteolytic activation. J Biol Chem 2003; 278: 22217-22222.

33 Danser AHJ, Batenburg WW, van Esch JHM, Krop M. Prorenin anno 2008. J Mol Med 2008; 86: 655-658.

34 Nabi AHMN, Suzuki F. Biochemical properties of renin and prorenin binding to the (pro)renin receptor. Hypertens Res 2010; 33: 91-97.

35 Feldt S, Batenburg WW, Mazak I, Maschke U, Wellner M, Kvakan H, Dechend R, Fiebeler A, Burckle C, Contrepas A, Danser AHJ, Bader M, Nguyen G, Luft FC, Muller DN. Prorenin and renin-induced ERK $1 / 2$ activation in monocytes is not blocked by aliskiren or the handle-region peptide. Hypertension 2008; 51: 682-688.

36 Krop M, Garrelds IM, de Bruin RJA, van Gool JMG, Fisher NDL, Hollenberg NK, Danser AHJ. Aliskiren accumulates in renin secretory granules and binds plasma prorenin. Hypertension 2008; 52: 1076-1083.

37 Franken AAM, Derkx FHM, Man in't veld AJ, Hop WCJ, van Rens GH, Peperkamp E, de Jong PTVM, Schalekamp MADH. High plasma prorenin in diabetes mellitus and its correlation with some complications. J Clin Endocrinol Metab 1990; 71: 1008-1015.

38 Makimattila S, Summanen P, Matinlauri I, Mantysaari M, Schlenzka A, Aalto M, Irjala $\mathrm{K}$, Yki-Jarvinen H. Serum total renin, an independent marker of the activity and severity of retinopathy in patients with IDDM. Br J Ophthalmol 1998; 82: 939-944.

39 Ichihara A, Kaneshiro Y, Takemitsu T, Sakoda M, Nakagawa T, Nishiyama A, Kawachi H, Shimizu F, Inagami T. Contribution of non-proteolytically activated prorenin in glomeruli to hypertensive renal damage. J Am Soc Nephrol 2006; 17: 2495-2503.

40 Nakamura N, Satomura S, Matsuura S, Murakami K. Identification of the active site of human renin with use of new fluorogenic peptides. J Biochem 1991; 109: 741-745.

41 Nabi AH, Uddin MN, Nakagawa T, Orihashi T, Ebihara A, Iwasawa A, Nakamura Y, Suzuki F. Roles of His9 (P2 subsite) and His13 (P3' subsite) in angiotensinogen for catalytic reaction of renin. Int J Mol Med 2005; 16: 103-107. 